\title{
Diseases of Shoot, Stem and Root on Eucalyptus pellita F.Muell. at Sebulu, East Kalimantan
}

\author{
Iin Arsensi $i^{1, *}$ Djumali Mardji ${ }^{2}$ \\ ${ }^{1}$ Laboratory of Plant Protection, Faculty of Agriculture, Widya Gama University, Samarinda, Indonesia \\ ${ }^{2}$ Laboratory of Forest Protection, Faculty of Forestry, Mulawarman University, Samarinda, Indonesia \\ "Corresponding author. Email: iinarsensi@uwgm.ac.id
}

\begin{abstract}
This study aimed to determine the symptoms and signs of diseases on the shoot, stem, root, the causal agent, and the disease's incidence and severity. The most resistant families and the most detrimental pathogen were also discussed. The study was conducted at Surya Hutani Jaya Concession, Sebulu in Kutai Regency, East Kalimantan Province, and continued to identify the pathogen in the Laboratory of Forest Protection, Faculty of Forestry, University of Mulawarman. The study's object was E. pellita progeny test of 6 years old, with a spacing of $3 \mathrm{~m} \times 2 \mathrm{~m}$, and at the nursery. The seed was originated from the clone of Riau (Sumatera). The study revealed that there was a dieback disease caused by Botryosphaeria sp., stem canker by Coryneum sp., root rot by Ganoderma sp. and termite Coptotermes sp. at the plantation, while at the nursery was found damping-off caused by Fusarium sp., leaf feeders of locust Atractomorpha crenulata and leaf roller caused by caterpillar Strepsicrates sp. The incidence of dieback disease at plantation ranged from $79.2 \%$ to $6.3 \%$, stem canker was only one tree (47.9\%), root rot was also only one tree $(46.8 \%)$, and termite attack ranged from $70.8 \%$ to $39.6 \%$. The severity of dieback disease at plantation ranged from $22.2 \%$ to $4.2 \%$, stem canker $1.4 \%$, root rot $2.8 \%$, and termite attack ranged from $4.2 \%$ to $1.4 \%$.
\end{abstract}

Keywords: Eucalyptus pellita, Shoot, Stem, Root

\section{INTRODUCTION}

Eucalyptus pellita F.Muell. (family Myrtaceae) is one of the species that is prioritized in industrial plantation forest, because of its adaptability to its new habitat and the wood can be used for raw materials of pulp and paper. The development of this species in Kalimantan and Sumatera has shown good growth of the stem shape, growth speed, high wood quality, and have high sprouting ability [1]. This species can also be used for building construction materials and has long been used for materials in the charcoal industry in Brazil [2].

The species is often planted in monoculture, so it is often susceptible to disease. Given the widespread expansion of E. pellita in Kalimantan in general and in East Kalimantan in particular, more intensive research is needed. Because the wood is precious and in an extensive area, even a small decrease in increment needs to be prevented from experiencing losses. Decreased increments can be caused by pathogens, both from biotic and abiotic factors.
Old et al. [3] stated that many types of diseases attack Eucalyptus spp. from the level of seedlings to trees and from roots to leaves; most of the causes are fungi. For example, in a crop, 13-month-old E. pellita in northern Queensland in 1996 was attacked by a bacterium Ralstonia solanacearum, resulting in many plants experiencing leaf wilting. In plantations near Pekanbaru (Sumatera), Ganoderma attacks the roots of E. pellita trees and causes death. Black mildew caused by the fungus Meliola densa also attacked a hybrid of $E$. pellita $\times E$. brassiana in a trial of provenance and family effect in Melville Island (north of Australia), but this species was resistant to leaf rust disease caused by Puccinia psidii. In Queensland and Vietnam, this species is also known to be resistant to leaf blight caused by Calonectria reteaudii, stem canker of Cryphonectria cubensis, and Cryptosporiopsis eucalypti. Arsensi and Mardji [4] had reported leaf diseases on E. pellita in Surya Hutani Jaya Concession.

Eucalyptus species most resistant to leaf blight is $E$. grandis $\times E$. pellita and the most virulence of leaf blight is Cylindrocladium sp. against $E$. grandis $\times E$. pellita. 
Botryosphaeria appendiculata fungi cause dieback (dead shoots) on E. pellita found in Melville Island, Australia. According to Harding et al. [5] E. pellita is susceptible to stem borer Lyctus brunneus.

Currently, in PT Surya Hutani Jaya Company (PT SHJ) at Sebulu is being developed E. pellita which comes from selected seeds and clones called family. The selection is intended to produce superior families so that the wood productivity increases to meet the shortage of raw materials for the pulp and paper industry. To get these superior families, PT SHJ has built E. pellita test plant known as Progeny Full Test Sib, in which the plant material comes from seeds of known both parents (male and female) as wide as 14.4 ha in Sumatera. To find out the advantages of the trees, the company deliberately does not maintain this area. Later, trees can be produced by trees (families) that excel in productivity and resistance to pests and diseases.

This study was conducted to find out the symptoms and signs of shoot, stem and root disease in E. pellita in the progeny test and nursery area; the causal pathogens; incidence and severity of pathogenic attacks; the family which is the most resistant; species of diseases that are potentially the most detrimental.

\section{METHOD}

\subsection{Location and Fieldworks}

Fieldwork was conducted in PT SHJ at Sebulu, Kutai Regency, East Kalimantan. Fieldwork was carried out from November 2012 until November 2013 and continued with the research in the Laboratory of Forest Protection, Faculty of Forestry, the University of Mulawarman in Samarinda. The research object was $E$. pellita of 6 years old in the progeny test area of block $35 \mathrm{~A}$, zone 34 , consisting of 30 families, clone origin of Riau. The trees in the sub-plot were 12 trees, replicated six times, so the sum of trees was 30 families $\times 6$ replicated $\times 12$ trees $=2160$ trees. Plant spacing was 3 $\mathrm{m} \times 2 \mathrm{~m}$, the large subplot was $72 \mathrm{~m}^{2}$.

Data collected in the field were symptoms and signs of pathogenic attack, total diseased and alive trees. The severity of the pathogen attack was determined based on tree conditions modified from Mardji [6] (Table 1).

Table 1. Determine the score attack of pathogens on each tree of E. pellita

\begin{tabular}{l}
\hline Condition of tree \\
\hline Healthy: no symptoms of attack or presence, but the number of affected leaves are very few compared to the \\
total number of leaves; the canopy is very lush to thick. \\
\hline Light attack: the number of leaves and number of attacks on each of the affected leaves is few or loss or \\
chlorotic leaves is few or plant looks healthy, but there are other symptoms such as stem canker, the canopy is \\
lush to rare. \\
\hline Moderately attack: the number of leaves and number of attacks on each of the affected leaves rather a lot or \\
loss or chlorotic leaves rather a lot or is accompanied by other symptoms such as stems canker, the canopy is \\
rather sparse. \\
\hline Severe attack: the number of leaves and number of attacks on each of the affected leaves is many or many \\
leaves are fall or many chlorosis or are accompanied by other symptoms such as stem canker, canopy is rare. \\
\hline Dead: entire leaf wilting or loss or no signs of life
\end{tabular}

Identifying disease-causing microorganisms was done by attaching the adhesive tape to the trunk or the upper and lower of affected leaves, embedded in an object-glass, and then examined with Nikon's binocular microscope UFX. Literature used for the identification of pathogens were "Illustrated genera of imperfect fungi" by Barnett and Hunter [7] and "A manual of diseases of eucalypts in south-east Asia" by Old et al. [3].

Symptoms and signs of the attack were explained qualitatively. Disease incidence (I) was calculated by comparing the number of trees attacked by the total number of observed trees in terms of percent according to James [8] as follows: $\mathrm{I}=(\mathrm{n} / \mathrm{N}) \times 100 \%$. Where $\mathrm{n}=$ number of diseased and dead trees. $\mathrm{N}=$ number of observed trees. Disease severity (S) was calculated using a modified formula of de Guzman [10], Singh and Mishra [11] as follows:

$\mathrm{S}=\{(\mathrm{X} 1 \mathrm{Y} 1+\mathrm{X} 2 \mathrm{Y} 2+\mathrm{X} 3 \mathrm{Y} 3+\mathrm{X} 4 \mathrm{Y} 4) / \mathrm{XY} 4\} \times 100 \%$

Where $\mathrm{X}=$ number of observed trees. $\mathrm{X} 1=$ number of trees having a score $1 . \mathrm{X} 2=$ number of trees having score 2. $\mathrm{X} 3$ = number of trees having score $3 . \mathrm{X} 4=$ number of trees having score $4 . \mathrm{Y} 1$ to $\mathrm{Y} 4=$ score of 1 to 4. To determine the condition of stand and level of resistance of each family of $E$. pellita against disease are shown in Table 2. 
Table 2. Stand condition and resistance level of each family of E. pellita to disease

\begin{tabular}{ccc}
\hline The severity of disease (\%) & Stands condition & Resistance level \\
\hline $0-1$ & Healthy (H) & Highly resistant (HR) \\
$>1-25$ & Moderately damaged (MD) & Resistance (R) \\
$>25-50$ & Heavy damaged (HD) & Vomalnerable (V) \\
$>50-75$ & Very heavy damaged (VHD) & Highly susceptible (HS) \\
\hline
\end{tabular}

\section{RESULT AND DISCUSSION}

\subsection{Incidence and Severity of Pathogen Attack in Progeny Test Area}

Death symptoms indicate dieback disease in the shoot section followed by branch death, twigs, and the entire canopy's death. The infection spreads to the base, so the main stem dies, but the surviving stems sometimes grow new shoots, which cannot last long because the pathogens continue to spread towards the stem's base so that all parts of the tree die. The healthy wood part is white, bordering with the infected one, dark brown if the dead bark is peeled. The cause is a fungus Botryosphaeria sp. The fungus spores are round to oblong, light brown to dark in colour, consisting of one cell and a nucleus inside.

This disease is the most widely found at the study site. The highest average incidence of attacks was in family Ep24 (79.2\%) and the lowest in family Ep28 $(6.3 \%)$. The highest average of severity was in the family Ep19, and Ep21 (22.2\%, respectively), and the lowest was in the family Ep30 (4.2\%).

There were 17 families whose incidence of dieback disease is above $50 \%$, while 13 families with a severity below $50 \%$. The severity of all families was below $25 \%$. The stand at the study site could be categorized as low damage; the resistance level of the stand was resistant to dieback disease.

\subsection{Climate Conditions}

\subsubsection{Stem Canker}

Stem canker is damage that occurs on the stem of the plant. This disease is very detrimental because the wood structure is damaged, and in severe attacks, the wood cannot be used. The cause of stem canker in $E$. pellita in the progeny test area was a fungus Coryneum sp. The spores are dark, consisting of several oblong round cells with a slightly tapered tip. The symptoms are opened bark and visible part of the wood, which is limited by callus. The thick sap comes out of the opened bark, and the canker extends from the base of the stem to the top; the tree's growth is not good; under the infection, sometimes new buds grow (epicormic branches).

The tree damaged by stem canker may be caused by injury to the stem followed by pathogens' entry. Stem canker pathogens are more active in high rainfall areas, where there are many susceptible plants [3]. The causes of stem canker, in general, are fungi of various species. Tree species of E. pellita is moderately resistant to the stem canker Cryphonectria cubensis, but the sapwood is susceptible to attack by Lyctus borers [9].

Stem canker was just found in family Ep14. The average stem canker incidence was $47.9 \%$, and the average severity was $1.4 \%$. The incidence of stem canker disease was less than $50 \%$, and the severity was less than $25 \%$, so that the condition of the stand in the study site was categorized as low damaged with resistance levels was resistant.

\subsubsection{Root Rot}

The part of the tree attacked is the base of the stem and roots, the base of the stem is rot and easy to fall, on the bark of the stem base is dark in color, the leaves turn yellow, and fall, branches, and twigs die, so the tree becomes bare. There are fine white threads that, when moistened turn yellowish, a fruit body is growing on the stem's base. The fruit body's shape is like a fan, semicircular, hard, woody, and the bottom surface is white; the upper middle is dark brown and can reach a size of $40 \mathrm{~cm}$. The cause is a fungus Ganoderma sp.

Root rot is a disease that spreads through the soil (soil-borne disease) through contact between healthy plant roots with the source of diseased inoculum; in this 
case, the inoculum source can be stumped, dead roots that have been attacked by root rot pathogen. When this study was carried out, many former Acacia mangium dead stumps might be caused by Ganoderma sp. This transmission can occur due to contact between healthy $E$. pellita roots with the remnants of the infected roots of A. mangium in the soil. According to Boyce [10] root rot may be caused by various Ganoderma species (Ganoderma spp.), which is very damaging, especially in tropical areas where natural forests are converted into plantations extensively. Agustini et al. [11] reported that root rot in E. pellita at PT Arara Abadi (Sumatera) was caused by G. philippii and Phellinus noxius.

Root rot found in E. pellita is very detrimental because it causes tree death since infected roots cannot function properly as it is known that the roots play a role in supporting the establishment of trees. Physiologically, the root is one of the plant's vital organs because it functions as an absorber of nutrients and water for the plant's growth and development.

Root rot disease was just found in the family Ep11 with an incidence of $45.8 \%$ and the severity of $2.8 \%$, then the stand of E. pellita in the progeny test was categorized as low damaged in the level of resistance.

The incidence of root rot disease was less than $50 \%$, and the severity was less than $25 \%$, so that the condition of the stand in the study site was categorized as low damaged with resistance levels was resistant.

\subsubsection{Stem and Root Damage}

A species of termite caused damage of the stem and root on E. pellita trees in progeny test, namely Coptotermes sp. The trunk is covered with soil groove starting from the stem's base up to the tree's height. The attack is to circle the stem, and there is also a straight groove up. If the soil is dismantled, there are many holes in the trunk where termites present. The hole size is 1 to $2 \mathrm{~mm}$. The soil protects termites from parasites, predators, and physical factors such as rain, wind, and light. The hole size is 1 to $2 \mathrm{~mm}$. The soil protects termites from parasites, predators, and physical factors such as rain, wind, and light.

At first glance, termites are small insects similar to ants found in many places, in forests, yards, gardens, and even inside homes. Termite nests are found in damp places in the soil and wet logs, but some live in dry wood. The main foods are wood and other cellulose materials, and fungi [12]. Termites taxonomically grouped into the order Isoptera (iso $=$ equal and ptera $=$ wing). Termites have soft, light-colored bodies. The number of termite species globally is about 2,648 species classified into seven families and 281 genera. Coptotermes sp. is including one of the termites of the family Rhinotermitidae [13].
Soil termites are a group of termites that cause the most economic losses. Genera Coptotermes is the most termite that damages wood and other woody materials on the soil. According to Tarumingkeng [14]. The soil termite has the highest attack power, and even the attack can reach the $26^{\text {th }}$ floor of a multi-storey building. Coptotermes sp. may found in many tropical and subtropical regions, with $45 \%$ of its species found in the tropics. In central Sumatera, it is reported that the termite damaged one-year-old Acacia sp. as large as 10$50 \%$ [15]. Subterranean termites enter wood through the soil or the protective passageways. This termite species require specific humidity regularly [16]. The temperature range preferred by termites is $21.1-26.7^{\circ} \mathrm{C}$ and optimum humidity is $95-98 \%$ [17]. When this study was conducted, it had entered the rainy season where the average rainy day was ten days/month with an average rainfall of $194.5 \mathrm{~mm} / \mathrm{month}$. According to Schmidt and Ferguson, the value is above average when connected between the average in the field and the average rainfall classification, so it is possible for high termite attack rates because of the environmental conditions that support them for breeding.

The highest average termite incidence was in the families Ep3 and Ep26 (70.8\%) and the lowest in the family Ep16 (39.6\%). The highest average termite severity was in the family Ep4 (4.2\%), and the lowest was in families Ep7, Ep16, Ep18, Ep22, and Ep26 ( $1.4 \%$, respectively).

Termite attacks were not so much found in the study site; there were only found in 9 families, where seven families had an incidence above 50\% and two families with a severity less than $50 \%$. The severity in all families was less than $25 \%$, so that the condition of the stand in the study site could be categorized as low damaged. The resistance level was resistant to termite attacks.

\subsubsection{Stem Rot}

There was stem rot disease on seedlings of E. pellita. The attack starting from the lower leaf towards the top of the stem, the affected leaves are brown and wilted, the affected part of the stem is brown, and there are fine white threads of hyphae; the stems and leaves are still reddish-green, visible the boundary between healthy bark and the sick. The cause is a fungus Fusarium sp. The conidia consist of macroconidia, curved, bulkhead, long with narrowing tips. In contrast, microconidia are oval with one or without bulkhead, and their size is much smaller than the macroconidia.

According to Stevens [18], the genera Fusarium consists of many species and many synonyms, of which around 400 species are recognized, which are primarily parasitic in plants and very harmful. The infected parts mostly were transport vessels which caused leaf wilting, 
while other species gave rise to leaf rot, leaf blotches, the canker of the stem, and many more. If it does not get the host, the species lives saprophytically; then, it turns into a parasite if it gets a suitable host and vulnerable.

In E. pellita, Fusarium spp. has been known to attack seed, both while still in trees, in storage, and on germinating seed [19]. In Argentina, Fusarium sp. often cause damping-off on Eucalyptus spp. seedlings in the nursery [20]. Fusarium sp. is also reported as a cause of damage to rubber sheets that have not yet been processed in Bangladesh [21].

\subsection{Insect Pest in the Nursery}

\subsubsection{Leaf Feeder}

There was a species of grasshopper found in the nursery of E. pellita at Surya Hutani Jaya Company. It was Atractomorpha crenulata. The characteristics are same as described by Radhakrishnan and Rajan (n.d.); Inflibnet Centre (n.d.) among others the body long and slender, green, head conical rarely longer than the pronotum, fastigium as long as the eye, frontal ridge compressed between the antennae, antennae short transurethral, sulfiliform, eyes oblong, abdomen smooth, legs long and slender.

At the nursery of Surya Hutani Jaya Company, symptoms of $A$. crenulata attack are the presence of bite marks on young leaves of $E$. pellita seedlings which are irregular in shape and starting from the edge of the leaf. According to Lakitan [22] one of the functions of leaves is the place where photosynthesis occurs, leaves of plants contain lots of carbohydrates or photosynthetic food reserves, so pests generally like to eat leaves, especially young ones. This grasshopper on E. pellita in the nursery did not cause much damage because the number of individuals was relatively small.

The grasshopper nibble leaf lamina causing irregular holes. Most species feed on grass. Some species feed on other vegetation, including leaves and stems, even feed on dead Eucalyptus leaves. Under some conditions, some species will migrate in a dense swarms form, known as locusts, bringing considerable damage to the crop (Inflibnet Centre, n.d.). The grasshopper $A$. crenulata preferred Daucus carota, Adiantum caudatum, and Hemartheria compressa the most amongst 13 plant species [23]. This grasshopper is found in many East Java districts on mung bean gardens but in low abundance [24]. It is a highly polyphagous pest with a vast range of host plants, both cultivated and wild (Eagri, n.d.). This species (also called tobacco grasshopper) has many hosts; almost all plant species become their hosts, ranging from crops and plantations to forestry [25]. The distribution is in India, Myanmar, Bangladesh, Indonesia, Sri Lanka, and South Vietnam [26].

\subsubsection{Leaf Roller}

Caterpillars of the leaf roller feed on the leaves and buds of the seedlings. A protective shelter from which the leaf roller feeds make up of combined silken threads and foliage. The caterpillar constructs several shelters and sometimes, it is found more than one leaf roller within an assemblage of the webbed leaf. Insect shelters inside the leaf roll, feeding on the plant tissue within. The attacked leaves become skeletonized and die. The causal leaf roller is a caterpillar Strepsicrates macropetana.

In the nursery of E. pellita at the study site, this caterpillar was not caused extensive damage. Still, according to Mauchline et al. [27], it has become a pest of increasing economic importance to young eucalypt plantations in New Zealand, and Nuttall [28] recorded the caterpillar $S$. macropetana has been found on at least fifteen Eucalyptus species (Myrtaceae) in New Zealand, including E. botryoides, E. fastigata, E. nitens, E. obliqua, E. regnans and E. saligna. This caterpillar feeds primarily on juvenile foliage, but older leaves may also be attacked. Its larva forms damaging life stage by feeding on the shoot tips, buds, and developing flowers, which are adhered together with webbing [29].

\subsubsection{Potentialy Detrimental Pathogen}

A potentially harmful disease is the trees in the progeny test, while in the nursery, there is no problem with the disease because the company has conducted intensive supervision. In the progeny test, dieback disease was due to Ganoderma sp. and Botryosphaeria sp. resulting in deterioration of canopy function, especially for photosynthesis, so that the tree eventually dies.

The causal agent of stem canker disease was just one species, namely Coryneum sp. Although just found one species of pathogen, this fungus is potentially detrimental because it damages the stem of E. pellita, where the end product of the plantation is wood. The stem canker will reduce the economic value of the stem.

Pathogen attacks on roots of trees can cause losses in the future because they can interfere with the translocation process to reduce the wood production of E. pellita. The function of the plant's roots is as an organ to absorb nutrients and minerals from the soil and is transported to other parts of the plant through the transport network. If the E. pellita plant's root is disturbed by the pathogen's infection, the translocation process will be inhibited so that the plant will die.

The species of termite found in the progeny test was just one, namely Coptotermes sp. Although there were only nine families of trees attacked by the termite, it caused physical damage directly to E. pellita and caused a decrease in wood production, causing economic 
losses. This is because these termites can attack the roots and stems of E. pellita plants so that the translocation of water and nutrients from the soil is disturbed, and eventually, the plants die.

The cause of stem rot in the nursery was found in just one fungus species, namely Fusarium sp. The pest found were two species, grasshoppers (A. crenulata) and leaf roller caterpillars (Strepsicrates $\mathrm{sp}$.$) .$

All species of pathogens mentioned above found in the progeny test and the nursery are potentially harmful if eradication is not carried out early. Moreover, monoculture planting conducted in the field may become susceptible to disease if it comes from susceptible parents. This is where it is vital to establish a progeny test to get a superior parent, both superior in growth and superior in its resistance to disease.

\section{CONCLUSION}

There were four diseases in plantation, namely dieback disease, stem canker, root rot, and termite attack, while in the nursery, there were three diseases, namely damping-off, leaf feeders, and leaf roller. They were potentially detrimental diseases if supervision and care are lacking attention. At the progeny test, the area and trees were deliberately not maintained to determine the tree's resistance to disease. But the trees in the progeny test and seedlings in the nursery damage the disease is not too extensive. Based on the severity of the attack, the following families are categorized as resistant, Ep1, Ep2, Ep7, Ep16, Ep20, Ep22, and Ep30. The trees of these families were utterly free from disease infection. Progeny test stand was just six years old when this study was conducted; therefore, further research was needed until the trees were old, so trees were found to be resistant to the disease.

\section{REFERENCES}

[1] B. Leksono, Potensi Eucalyptus pellita untuk pembangunan hutan tanaman industri (HTI) dan pengembangan program pemuliaan pohon, Makalah Simposium Nasional dan Kongres IV PERIPI, P3BPTH, Yogyakarta, 2001. [Indonesian]

[2] Y. Widyana, M. Naim, S. Danarto, Studi pendahuluan teknologi pembungaan Eucalyptus pellita F.Muell di Wanagama I Gunung Kidul, Yogyakarta, in: E.B. Hardiyanto (Ed.), Prosiding Seminar Nasional Status Silvikultur 1999. Fakultas Kehutanan UGM, Yogyakarta, 2000. [Indonesian]

[3] K.M. Old, M.J. Wingfield, Z-Q. Yuan, A manual of diseases of eucalypts in South-East Asia. Center for International Forestry Research, Bogor, 2003.

[4] I. Arsensi, D. Mardji, Leaf diseases on Eucalyptus pellita in plantation forest at Sebulu, East
Kalimantan, Int. J. Forest, Soil and Erosion, 6(4), 2016, pp. 131-139.

[5] K. Harding, G. Hopewell, M. Davies, A. Zbonak, The wood properties of tropical and subtropical hardwood plantation timber grown for high-value products in Australia, Technical Report 224, 2012. Accessed September 26, 2016.

[6] D. Mardji, Hama dan penyakit tanaman jenis Dipterocarpaceae di Bukit Soeharto. Laporan Penelitian Lembaga Universitas Mulawarman, Samarnda, 1996, p. 94. [Indonesian]

[7] H.L. Barnett, B.B. Hunter, Illustrated genera of imperfect fungi. Fourth edition. The Phytopathological Society, St. Paul, Minnesota, USA, 1998, p. 218.

[8] W.C. James, Assessment of plant diseases and loses. Ann. Rev. Phytopath, 12, 1974, pp. 27-48.

[9] C. Orwa, A. Mutua, R. Kindt, R. Jamnadass, S. Anthony, Agroforestry database: a tree reference and selection guide version 4.0, 2009 http://www.worldagroforestry.org/sites/treedbs/tree databases.asp. Accessed September 27, 2018.

[10] J.S. Boyce, Forest pathology. Third edition. Mcgraw-Hill Book Company, Inc., New York, 1961, p. 572.

[11] L. Agustini, A. Francis, M. Glen, H. Indrayadi, C.L. Mohammed, Signs and identification of fungal rootrot pathogens in tropical Eucalyptus pellita plantations. Forest Pathology, 44(6), 2014, pp. 486495. Doi:10.1111/efp.12145.

[12] M. Amir, Rayap dan Peranannya, dalam: M. Amir, S. Kahono, Eds., Serangga Taman Nasional Gunung Halimun Jawa bagian barat Biodiversity Conservation Project, LIPI, 2003, pp. 51-62. [Indonesian]

[13] S. Kambhampati, P. Eggleton, Taxonomy and phylogeny of termites. In: Abe T, Bignell DE, and Higashi M. (Eds.) Termites evolution. Sociality, symbioses, ecology, Springer, Dordrecht, 2000, pp. $1-23$.

[14] R.C. Tarumingkeng, Biologi dan perilaku rayap, 2001. http:tumoutou.net/biologiperilakurayap.htm. Accessed March 3 2011. [Indonesian]

[15] K.S.S. Nair, Insect pests and diseases in Indonesia Forests, CIFOR, Bogor, 2000, p. 91.

[16] K. Duljapar, Pengawetan Kayu, PT Penebar Swadaya, Jakarta, 1996. [Indonesian]

[17] D. Nandika, R. Yudi, F. Diba, Rayap, biologi dan pengendaliannya, Muhammadiyah Press, Surakarta, 2003. [Indonesian] 
[18] F.L. Stevens, The fungi which cause plant disease. Johnson Reprint Corporation, New York, 1966, p. 754.

[19] B.N. Brown, Diseases of fungi of the reproductive structure of eucalypts, in: P.J. Keane, G.A. Kile, F.D. Podger, B.N. Brown (Eds.), Diseases and pathogens of eucalypts, pp. 103-115. CSIRO, Colliwwod, Victoria, 2000.

[20] M.L. Salerno, G.A. Lori, D.O. Gimenez, J.E. Gimenez, J. Beltrano, Use of soil solarization to improve growth of Eucalypyus forest nursery seedlings in Argentina, New Forest, 20(3), 2000, pp. 235-248.

[21] S. Shamsi, P. Chowdhury, Mycoflora associated with rubber sheets and its management by common salt (sodium chloride), J. Asiat. Soc. Bangladesh Sci., 40(1), 2014, pp. 79-87.

[22] B. Lakitan, Dasar-dasar fisiologi tumbuhan. PT Rajawali Press, Jakarta, 2011, p. 244. [Indonesian]

[23] S. Nath, A. Rai, N. Chhetri, P. Lepcha, Food preferences of a pest grasshopper, Atractomorpha crenulata (Fabr.) (Orthoptera: Acridoidae) from Darjeeling Hill, Entomon, 34(2), 2009, pp. 111-113.

[24] S.W. Indiati, Bejo, M. Rahayu, Diversity of mung bean insect pests and their natural enemies in farmers' fields in East Java, Indonesia, Biodiversitas, 18(4), 2017, pp. 1300-1307. DOI: 10.13057/biodiv/d180403.

[25] Jumar, Entomologi serangga. PT Rineka Cipta, Jakarta, 2000, p. 237. [Indonesian]

[26] D.K.Mc.E. Kevan, The synonymy and distribution of the crenaticeps-group of Atractomorpha saussure, 1862 (Orthoptera, Acridoidea, Pyrgomorphidae). Zoological Journal of the Linnean Society, 50(2), 1971, pp. 143-159. DOI: 10.1111/j.10963642.1971.tb00756.x

[27] N. Mauchline, T.M. Withers, Q. Wang, L. Davis, Life history and abundance of the eucalyptus leafroller, Strepsicrates macropetana Meyrick. Proc. $52^{\text {nd }}$ New Zealand Plant Protection Conference, 1999, pp. 108-112.

[28] M.J. Nuttall, Strepsicrates macropetana Meyrick (Lepidoptera: $\quad$ Tortricidae), 1983. http://lepidoptera.butterflyhouse.com.au/tort/macro petana.html. Accessed September 2, 2018.

[29] C. Phillips, Insects, diseases and deficiencies associated with eucalypts in Australia. Primary Industries, South Australia, 1992, pp. 97-99. 